\title{
Kontribusi Aplikasi Sistem Informasi Geografis (SIG) Dalam Berbagai Skala Kajian Arkeologi Lansekap
}

\section{Jarwo Susetyo Edy Yuwono}

Keywords: remote sensing, GIS, spatial, area, theory, methods, practices, geography

\section{How to Cite:}

Yuwono, J. S. E. (2007). Kontribusi Aplikasi Sistem Informasi Geografis (SIG) Dalam Berbagai Skala Kajian Arkeologi Lansekap. Berkala Arkeologi, 27(2), 81-102. https://doi.org/10.30883/jba.v27i2.954

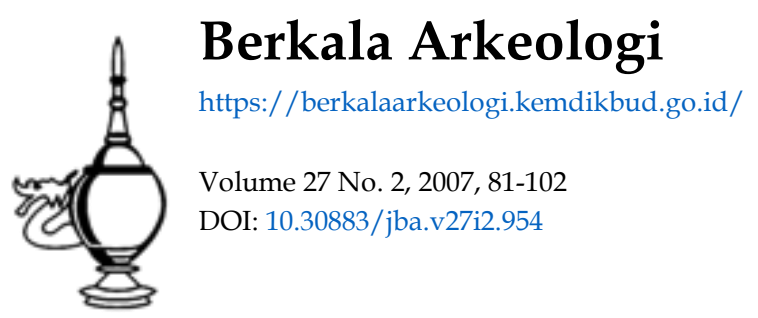

\section{(7) (7) (2)}

This work is licensed under a Creative Commons Attribution-NonCommercial-ShareAlike $\underline{4.0 \text { International License. }}$ 


\title{
KONTRIBUSIAPLIKASI SISTEM INFORMASI GEOGRAFIS (SIG) DALAM BERBAGAISKALA KAJIAN ARKEOLOGI LANSEKAP
}

\author{
J. Susetyo Edy Yuwono \\ (Jurusan Arkeologi FIB-UGM)
}

\begin{abstract}
Abstrak
Perkembangan Sistem Informasi Geografis (SIG) akhir-akhir ini telah berimbas pada kepentingan arkeologi, baik di tingkat pendugaan dan eksplorasi situs, presentasi distribusi situs, beragam jenis analisis dan pemodelan spasial, hingga ke tingkat pengelolaan sumberdaya arkeologi (PSA) khususnya untuk pengambilan keputusan. Di sisi kajian arkeologi, tuntutan dan tugas berat ke depan, adalah bagaimana disiplin ini mampu mengakses, mengolah dan menstrukturkan, menyajikan, dan meng-update terus-menerus semua informasi geo-kultural dalam dimensi bentuk, waktu, dan ruang yang semakin tak terbatas kompleksitasnya. Semua bentuk informasi geo-kultural beserta dinamikanya, yang menjadi substansi dari suatu kondisi lansekap, menuntut arkeologi untuk "berkiprah" dalam berbagai skala kajian secara multidisipliner. Keberadaan basisdata lansekap yang komprehensif dan terstruktur, serta kemampuan menganalisis dan mengevaluasi bentuk-bentuk interrelasi antar fenomena geosfera, adalah modal dasar bagi keberhasilan kajian seperti ini.
\end{abstract}

Kata Kunci: Sistem Informasi Geografis (SIG), Arkeologi Lansekap

\section{Sistem Informasi Geografis (SIG)}

\subsection{Pengertian Umum SIG}

SIG tumbuh sebagai respon atas kebutuhan akan pengelolaan data keruangan yang lebih efisien dan mampu menyelesaikan masalah-masalah keruangan. Para perencana dan pengelola sumberdaya alam maupun 
kalangan militer yang banyak menggunakan peta untuk menyajikan kondisi muka bumi, mulai merasakan bahwa pembuatan dan penggunaan peta manual memiliki banyak kelemahan. Selain sulit dilakukan perbaikan dan penambahan informasi, penggabungan peta dengan informasi dari sumber lain, apalagi secara multitema, tidak mungkin dilakukan. Dengan berkembangnya pemanfaatan komputer untuk penanganan data geografis pada awal tahun 1980an hambatan tersebut akhirnya dapat diatasi. Teknologi SIG pun berkembang dan terus-menerus mengalami penyempurnaan seiring dengan semakin banyaknya pihak-pihak yang memanfaatkannya (Suharyadi \& Danoedoro 2004).

SIG adalah suatu sistem untuk mengumpulkan, menyimpan, memanipulasi (memodelkan), menganalisis, dan menyajikan sekumpulan data keruangan yang memiliki referensi geografis atau acuan lokasi (Johnson 1996). Secara teknis, SIG juga merujuk pada suatu sistem informasi yang menggunakan komputer dan mengacu pada lokasi geografis yang berguna untuk membantu pengambilan keputusan (Puspisc UGM 2004).

\subsection{Komponen-komponen SIG}

Sebagai suatu sistem informasi, pengoperasian SIG memerlukan sekurang-kurangnya tiga komponen dasar yang terdiri atas hardware, software, dan brainware (Suharyadi \& Danoedoro 2004, Puspics UGM 2004). Hardware (perangkat keras) merupakan perangkat fisikal untuk melaksanakan pekerjaan secara keseluruhan, termasuk semua jenis peripheral masukan dan keluaran data. Beberapa jenis komputer, scanner, meja dijitasi, GPS reciever, kamera, printer, plotter, serta media-media penyimpan dan penayang data, merupakan bagian dari perangkat keras ini.

Software (perangkat lunak) mencakup program dan user interface untuk mengendalikan perangkat keras, baik berupa software sistem yang mengontrol kerja komputer secara umum, maupun software aplikasi yang melaksanakan fungsi-fungsi khusus sesuai kebutuhan pengguna. Beberapa jenis perangkat lunak yang umum digunakan di antaranya Arc/INFO, ArcView GIS, ArcGIS, MapInfo, ILWIS, AutoCAD Map, GRASS GIS, dan GeoMedia. Selain itu masih ada beberapa perangkat lunak lain untuk 
pekerjaan image processing yang berorientasi geografis, di antaranya ILWIS, ER Mapper, ENVI, PCI Geomatics, TNT Mips, IDRISI, dan ERDAS.

Perangkat lunak SIG memiliki kemampuan membaca data dari beragam format perangkat lunak lain, sehingga mampu mengatasi berbagai kendala dalam analisis spasial. Dengan kemampuan ini, upaya untuk saling mempertukarkan data yang menjadi masukan dan hasil yang menjadi keluarannya tidak perlu memaksa para pengguna untuk terlebih dahulu mengkonversi semua datanya menjadi format tertentu. ArcView GIS, misalnya, mampu mengintegrasikan file-file drawings format $C A D$ ke dalam lingkungannya tanpa harus terlebih dahulu mengkonversinya ke dalam themes atau shapefile ArcView GIS. Hanya dengan mengaktifkan ekstensi Cad Reader, para pengguna akan mampu membuat, menampilkan, dan mengaktifkan tema-tema secara langsung dari files drawing format CAD tersebut apa adanya; termasuk menyisipkan beberapa file secara simultan, memberikan simbol, warna, mengirim query, dan melakukan analisis sebagaimana halnya terhadap shapefiles ArcView GIS sendiri. Selain itu, para pengguna juga dapat melakukan operasi gabungan (joint operation) antara data tabel dengan fitur-fitur spasial di dalam drawings $C A D$, dan kemudian menganalisis hubungan-hubungan spasial, baik di antara unsurunsur spasial pada drawings $C A D$ maupun dalam sumber data yang lain. Fitur-fitur spasial di dalam file drawings $C A D$ yang dimaksud adalah dari perangkat lunak Autocad (format *.DWG dan format *.DXF) dan MicroStation (format *.DGN) (Prahasta 2004).

ArcView GIS dan ArcGIS, sebagai perangkat lunak aplikasi yang umum digunakan, memiliki kemampuan untuk mengkombinasikan sejumlah sumberdata terpisah, antara data grafis dan data atribut. Data grafis atau data spasial adalah data digital yang menggambarkan peta (permukaan bumi) yang meliputi koordinat, garis, dan simbol yang menunjukkan elemenelemen kartografis. Data atribut atau data tabular adalah tabel yang menggambarkan karakteristik, kualitas, atau hubungan kenampakan peta dan lokasi geografis (Suharyadi \& Danoedoro 2004, Johnson 1996).

Di samping kehandalannya dalam melakukan data capture (input), penyimpanan, pengeditan, pemodelan, analisis, sintesis, serta penayangan informasi, keistimewaan perangkat lunak SIG lainnya terletak pada konsistensinya dalam mensyaratkan sajian informasi spasial yang 
bereferensi geografis (berkoordinat). Semua fenomena geosfera dapat ditampilkan dan dikompilasikan secara tepat dan akurat. Keutuhan informasi spasial yang dibutuhkan, diproses, dan dihasilkan olehnya, menunjukkan eratnya hubungan antara SIG dengan berbagai bentuk sajian keruangan terutama peta, citra satelit dan data GPS reciever. Dengan kata lain, SIG tidak dapat dilepaskan dari peta dan hasil-hasil penginderaan jauh yang menjediakan data vital mengenai berbagai fenomena keruangan pada tingkat akurasi yang dapat dipertanggungjawabkan (Yuwono 2004).

Kedua jenis perangkat di atas (hardware dan software) tidak akan beroperasi secara maksimal tanpa perangkat pikir manusia (brainware) yang mengendalikan aspek tujuan, manfaat, alasan, dan justifikasi dalam penggunaan SIG. Dalam hal ini dibutuhkan beberapa kualifikasi keahlian sebagai komponen pelaku, di antaranya operator, teknisi, analis, pengambil keputusan, programer, kartograf, dan ahli penginderaan jauh. Sinergi dari mereka dibutuhkan untuk menjalankan empat kegiatan pokok dalam SIG, yang dikenal sebagai IMAP-model, meliputi (Puspics UGM 2004):

1. Input

2. Manajemen

3. Analisis/Proses

4. Presentasi/Output antara lain digitasi, scanning, transformasi data, konversi data, dan koneksi dengan perangkat lain (input device).

antara lain pengelolaan basisdata, struktur data, kamus data, metadata, standardisasi data, dan kontrol kualitas.

Basisdata yang dimaksud berupa kumpulan data grafis dan atribut (tabel) yang saling terkait menjadi satu kesatuan, yang dapat ditambah, diperbaiki, dan dipanggil kembali secara tepat untuk berbagai keperluan.

antara lain overlay, spatial joint, buffer, Digital Elevation Model (DEM), network, modelling, editing, kalkulasi dan integrasi data, serta klasifikasi dan rektifikasi.

meliputi map composition, print control quality, dan interactive maps, yang dapat menampilan peta-peta tematik (sintetik), tabulasi, dan sistem informasi spasial 
Pola pikir SIG, adalah bagaimana menghasilkan informasi yang sama sekali baru melalui bentuk-bentuk pemrosesan spasial terhadap tema-tema yang berbeda. Dalam pemrosesan data tersebut dibutuhkan pemahaman tentang inter-relasi logis antar unsur geografis untuk menghasilkan suatu sintesis, sebagaimana alur yang ditempuh dalam pembuatan peta-peta tematiksintetik. Tema-tema apa saja yang diperlukan dan bagaimana alur pemrosesannya, merupakan bagian dari brainware yang harus dikuasai untuk menghasilkan suatu informasi baru (lihat bagan 1).

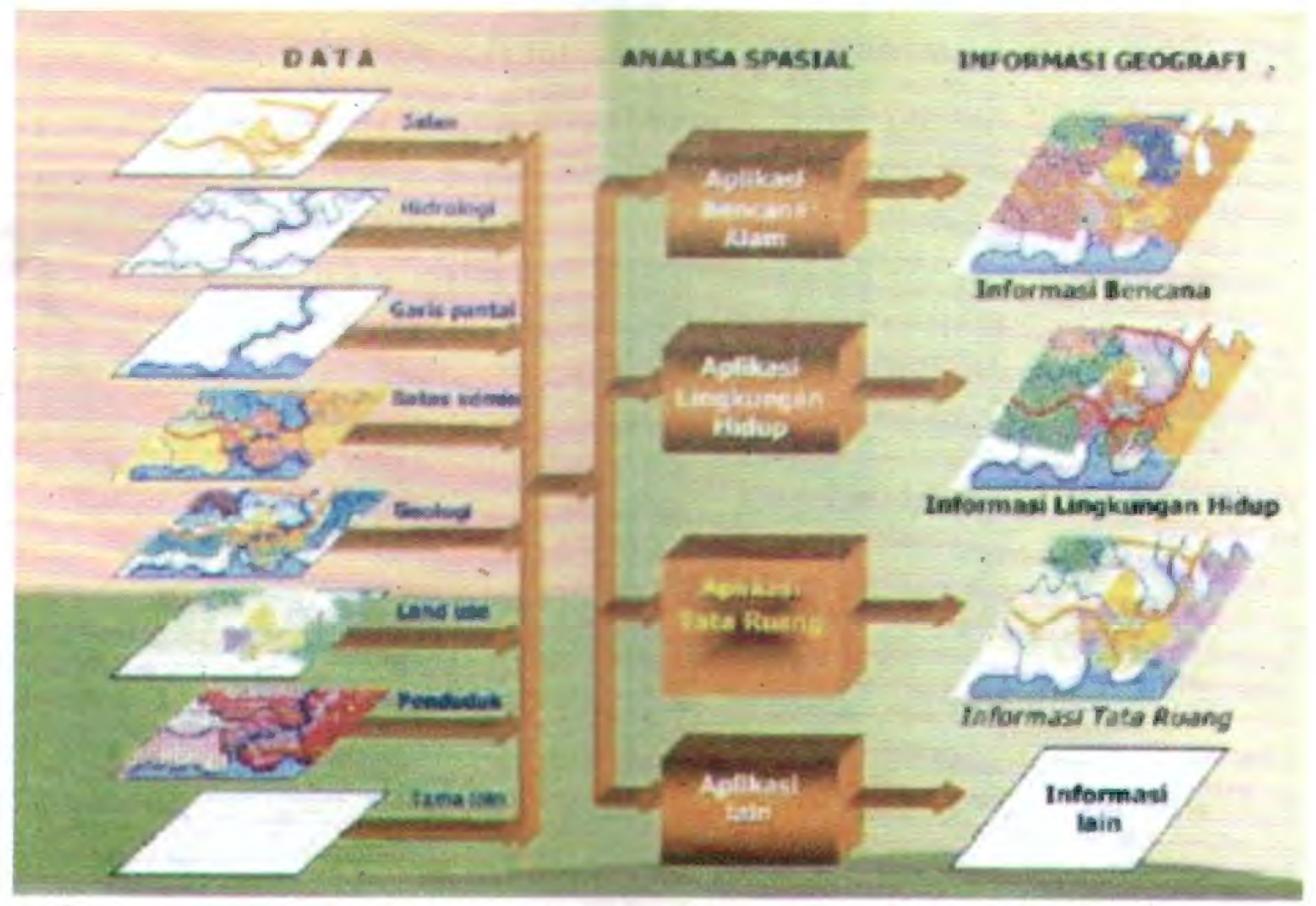

Bagan 1. Contoh Overlay peta multitema untuk membuat informasi baru

(Sumber: Puspics UGM 2004)

Sebagai contoh, dalam melakukan zonasi lahan, input datanya berupa petapeta komponen lahan (lereng, penggunaan lahan, sifat fisik dan kimia tanah, dan status lahan), dan keluarannya adalah Peta Zona Lahan (Suharyadi dan Danoedoro, 2004). Contoh lain mengenai alur pikir pemrosesan data yang memerlukan pengetahuan khusus tentang suatu fenomena alam adalah analisis bahaya erosi terhadap distribusi candi. Seringkali Peta 
Bahaya Erosi belum tersedia, sehingga harus dilakukan analisis multitema. Persoalannya adalah, tidak semua peta tematik sesuai untuk jenis kajian ini. Di sinilah perlunya pemahaman tentang fenomena erosi untuk menentukan tema-tema yang relevan, berupa Peta Curah Hujan, Peta Lereng, Peta Geologi/Tanah, dan Peta Penutup Lahan. Melalui proses overlay dan pengolahan data atributnya, gabungan peta tersebut akan menghasilkan Peta Bahaya Erosi. Dari sini dapat dilakukan zonasi bahaya erosi terhadap distribusi candi.

\subsection{Perkembangan SIG dan Relevansi Arkeologis}

Dewasa ini, SIG telah mengalami perkembangan yang cukup pesat, yang dipicu oleh sedikitnya tiga hal (Suharyadi \& Danoedoro 2004), yaitu perkembangan teknologi komputer dan sistem informasi; perkembangan metode analisis spasial dalam berbagai disiplin ilmu, terutama ilmu geografi dan ilmu keruangan lainnya; serta perkembangan kebutuhan aplikasi di berbagai bidang yang menuntut penanganan aspek-aspek keruangan dan pemodelan berbasis komputer.

Pesatnya perkembangan SIG memberikan manfaat secara timbal-balik kepada masing-masing komponen pelaku. Bagi para perancang/ pemrogram, misalnya, kerangka pikir SIG menuntut mereka untuk secara simultan mengembangkan skill dan konsep (pengetahuan) yang up to date dan multidimensional. Seorang operator sekalipun, tidak mungkin dapat mengoptimalkan pekerjaannya tanpa bekal konsep mengenaí output pekerjaannya. Bagi mereka, SIG adalah sebuah wahana dan sekaligus bentuk pembelajaran yang terstruktur. Sedangkan bagi para pengguna, SIG memberikan beberapa keuntungan di antaranya kemudahan, kecepatan, dan ketepatan dalam proses pengambilan keputusan; peningkatan pemahaman akan kondisi keruangan yang dihadapi; serta pengkayaan ide untuk mengembangkan kajian (Yuwono 2004). Jadi tidak mengherankan jika perkembangan SIG akhirnya diikuti dengan perkembangan metodologi ilmu-ilmu di sekitarnya yang memiliki basis keruangan, termasuk arkeologi.

Di bidang arkeologi, SIG mulai dikembangkan sejak diadakannya pertemuan ilmiah Society for American Archaeology di Amerika pada tahun 1985 yang bertemakan "Sistem Informasi Geografis (SIG) berbasis komputer: alat 
masa depan untuk memecahkan problema masa lalu" (Harris \& Lock 1990 dalam Rangkuti 1996). Perannya di bidang arkeologi semula adalah dalam konteks Pengelolaan Sumberdaya Arkeologi (PSA) yang banyak menerapkan analisis lokasional. Dalam aplikasi ini, SIG banyak memberikan masukan dalam proses pengambilan keputusan. Model prediksi yang dibangun memungkinkannya untuk diaplikasikan sebagai perangkat klasifikasi, kalkulasi, kombinasi, dan visualisasi kenampakan variabelvariabel spasial. Dengan berbagai kelebihan tersebut sangatlah beralasan untuk menjadikan SIG sebagai perangkat manajemen data utama dalam kegiatan PSA (Judge \& Sebastian 1988).

Peluang pengembangan SIG dalam kegiatan-kegiatan penelitian arkeologi murni pun semakin terbuka, dan jauh lebih luas daripada sekedar untuk menghasilkan peta-peta tematik. Salah satu kajian arkeologi yang menuntut pengaplikasian metode analisis spasial ini adalah kajian Arkeologi Lansekap, yang di dalamnya tercakup pula analisis-analisis Pola Pemukiman, Analisis Kewilayahan, dan model pendugaan situs.

\section{Arkeologi Lansekap}

\subsection{Pengertian Lansekap}

Istilah 'lansekap' secara umum memiliki makna yang hampir sama dengan istilah 'bentanglahan', 'fisiografi', dan 'lingkungan'. Perbedaan di antara ketiganya terletak pada aspek interpretasinya. Bentanglahan yang di dalamnya terdapat unit-unit bentuklahan (landforms) merupakan dasar lingkungan manusia dengan berbagai keseragaman (similaritas) maupun perbedaan (diversitas) unsur-unsurnya. Kondisi bentanglahan seperti ini memberikan gambaran fisiografis atas suatu wilayah. Wilayah yang mempunyai karakteristik dalam hal bentuklahan, tanah, vegetasi, dan atribut (sifat) pengaruh manusia, yang secara kolektif ditunjukkan melalui kondisi fisiografi, dikenal sebagai suatu lansekap (Vink 1983).

Batasan lansekap di atas adalah batasan dalam arti luas. Secara lebih spesifik, lansekap dapat diartikan sebagai wilayah atau suatu luasan di permukaan bumi dengan delineasi (batas-batas) tertentu, yang ditunjukkan melalui suatu geotop atau kelompok geotop (yaitu bagian geosfera yang relatif homogen dari segi bentuk dan prosesnya). Sebagai contoh, lansekap 
pegunungan struktural berbeda dengan lansekap dataran aluvial, daerah pesisir, perbukitan karst, daerah-daerah bentukan volkanik, fluvial, dan sebagainya. Batasan ini menekankan perlunya delineasi untuk memvisualisasikan suatu lansekap sebagai suatu unit spasial berdasarkan spesifikasi bentuklahan, vegetasi, dan ciri-ciri ubahan (artifisial) (Yuwono 2005).

Sesuai dengan karakternya, suatu lansekap dapat menampilkan gambaran yang kompleks dengan sifat yang bervariasi menurut jangkauan ruang dan waktu (Gisiger 1996). Kendati demikian, adanya dominasi unsur-unsur tertentu pada suatu lansekap akan mempermudah untuk mengenali jenisjenisnya, meliputi (dirangkum dari Bintarto 1991, Rangkuti, 1996, Yuwono 2005):

1. Natural Landscape, yaitu bentanglahan alami sebagai fenomena/ perwujudan di muka bumi, misalnya gunung dan laut. Kategori ini memiliki batasan yang paling umum, dan dapat disamakan dengan istilah "pemandangan" menurut terminologi umum.

2. Physical Landscape, yaitu bentanglahan yang masih didominasi unsur-unsur alam, yang diselang-seling oleh kenampakan budaya. Sistem kehidupan berikut komponen alami dan nonalami terwadahi dalam bentanglahan ini.

3. Social Landscape, bentanglahan dengan kenampakan fisik dan sosial yang bervariasi karena adanya heterogenitas adaptasi dan persebaran penduduk terhadap lingkungannya, misalnya kota dan desa dengan berbagai fasilitas individual maupun publiknya. Selain mencerminkan pola adaptasi, bentanglahan ini juga memvisualisasikan persepsi penduduk terhadap lingkungan sekitarnya. Dengan demikian, bentanglahan sosial merupakan zonazona yang menggambarkan struktur kehidupan sosial-ekonomi penduduk.

4. Economical Landscape, yaitu bentanglahan yang didominasi oleh bangunan beragam yang berorientasi ekonomis, seperti daerah industri, daerah perdagangan, daerah perkotaan, dan daerah perkebunan.

5. Cultural Landscape, merupakan bangunan/unsur budaya dengan natural features sebagai latar belakangnya, misalnya daerah pemukiman dengan kelengkapan sawah, kebun, dan 
pekarangannya. Bentanglahan ini merupakan hasil interaksi antara manusia dengan wilayahnya.

Meskipun kategorisasi di atas kadang-kadang sulit diamati secara tegas, namun secara umum dapat dikemukakan bahwa visualisasi suatu lansekap dibentuk oleh dua hal pokok. Pertama, perpaduan antara karakteristik alami dan non-alami dari ruang di permukaan maupun dekat permukaan bumi yang bersifat dinamis; Kedua, adanya hasil suatu perubahan berkesinambungan dari interaksi dinamis antar sfera, karena pada dasarnya bentanglahan merupakan ekspresi hubungan erat antar sfera dalam ruang dan waktu tertentu (Yuwono 2005). Penekanan studi ini terletak pada manfaat suatu bentanglahan untuk manusia dan pengaruh positif-negatif manusia terhadap bentanglahan.

\subsection{Pengertian Arkeologi Lansekap}

Berpangkal pada peristilahan geografis mengenai lansekap di atas, maka arkeologi pun memiliki kepentingan untuk melihat fenomena sebaran data/ situsnya dalam kerangka pemahaman lansekap. Berkembangnya pendekatan arkeologi lansekap yang semakin marak akhir-akhir ini tanpa disadari telah memperkaya kompeksitas dari lansekap itu sendiri.

Arkeologi lansekap yang mula-mula berkembang di Eropa, dapat dianggap sebagai hasil perkembangan baru di bidang metodologi ilmu pengetahuan berkat upayanya menempatkan isu-isu pemukiman manusia dalam konteks bentanglahan fisiknya. Penerapan pendekatan ini memberikan banyak keuntungan, bukan hanya bagi arkeologi, melainkan juga bagi kajian geografi manusia, yang keduanya saling melengkapi. Di satu sisi, kajian geografi manusia banyak berurusan dengan cara-cara manusia mengeksploitasi dan memodifikasi habitatnya, pola pemukiman, pasar dan jaringan komunikasi, serta kecenderungan-kecenderungan demografik. Bukti-bukti aktivitas manusia di dalam cakupan lansekap yang luas merupakan objek kajian bagi para ahli geografi manusia (Dennell 1987).

Di sisi lain, arkeologi lebih menitikberatkan penelitiannya pada wilayahwilayah yang memiliki bukti-bukti budaya bendawi, antara lain melalui ekskavasi atau rekonstruksi ekologi. Dengan mendasarkan kepada pandangan geografi, arkeologi pun mulai memperluas kajiannya dari area- 
area yang terbatas ke dalam kajian pola adaptasi dan pemukiman pada skala regional. Bahkan, bukan hanya masalah pemukiman, ketersediaan sumberdaya alam dan pengaruh peningkatan populasi manusia terhadap fauna dan flora, yang menjadi kajian ekologi bentanglahan (Moran 1990), akhirnya tidak luput pula dari kajian arkeologi lansekap.

Dengan mengamati sekurang-kurangnya dua komponen terkait, yaitu komponen fisik dan budaya, maka arkeologi lansekap dapat dikategorikan sebagai studi perbatasan yang mensinergikan aspek-aspek fisik dan budaya, serta inter-relasi di antara keduanya hingga membentuk fenomena bentanglahan masa lalu. Secara fisik, di sini diperlukan klasifikasi untuk menyederhanakan bentanglahan yang kompleks di permukaan bumi menjadi unit-unit bentuklahan yang mempunyai kesamaan dalam hal sifat dan perwatakannya (Verstappen 1983; Dibyosaputro 1997).

Bentuklahan, yang merupakan bagian dari permukaan bumi dengan kekhasan bentuk akibat proses dan struktur geologi selama periode perkembangannya, merupakan salah satu komponen bentanglahan yang perlu dikenali dan didelineasi. Verstappen (1983), telah mengelompokkan sembilan satuan bentuklahan berdasarkan genesanya (asal-usul), yaitu bentuklahan bentukan asal volkanik, struktural, denudasional, fluvial, marin, angin, pelarutan, grasial, dan aktivitas organisme. Masing-masing bentukan ini akan mengalami perkembangan seiring dengan waktu dan intensitas proses geomorfik yang mempengaruhi, sehingga stadium proses yang telah berlangsung, bahkan yang akan berlangsung dapat dikenali dan diprediksi. Selain bentuklahan, unsur-unsur fisik lain yang ikut membentuk suatu lansekap adalah tanah, air, dan vegetasi.

Di sisi lain, arkeologi banyak berurusan dengan aspek-aspek budaya, baik yang bersifat teknologis, sosiologis, maupun ideologis. Interaksi dari aspek fisik dan budaya ini menentukan corak-corak morfologi, morfogenesa, morfokronologi, dan morfoasosiasi, yang berdampak pada kesesuaian fungsi ruang, kualitas ruang, bentuk adaptasi, evolusi budaya, proses transformasi, aksesibilitas, ketersediaan sumberdaya alam, dan sebagainya.

Keterlibatan aspek budaya dalam membentuk suatu lansekap seringkali menimbulkan bentuk-bentuk anomali yang "menyimpang" dari sifat asli 
suatu bentuklahan. Gejala anomali yang dimaksud di antaranya adalah penyimpangan pada pola aliran sungai (pola drainase), pola kontur, pola kelurusan, pola penggunaan lahan (landuse), gejala perubahan muka airtanah, dan berbagai kenampakan fitur ubahan lainnya. Kunci utama untuk mengenali adanya anomali ini adalah mengetahui bagaimana pola alami yang seharusnya terbentuk pada suatu bentuklahan. Melalui berbagai penyimpangan bentuk inilah campurtangan manusia pada masa lalu dapat diketahui.

Dengan demikian, arkeologi lansekap mengandung pengertian sebagai cabang arkeologi yang menekankan kajian dan pendekatannya pada hubungan antara corak dan sebaran fenomena arkeologis dengan karakteristik perubahan bentanglahan/fisiografi sekitarnya. Bagaimana mengenali dan menjelaskan perubahan lansekap akibat pengaruh manusia; bagaimana kondisi lansekap mengontrol bentuk-bentuk campur tangan manusia; dan bagaimana memvisualisasikan dan menjelaskan hubungan antara manusia dengan lansekap hingga terbentuk lansekap ubahan, adalah pertanyaan-pertanyaan besar yang harus terjawab melalui kajian arkeologi lansekap (Yuwono 2005, lihat bagan 2).

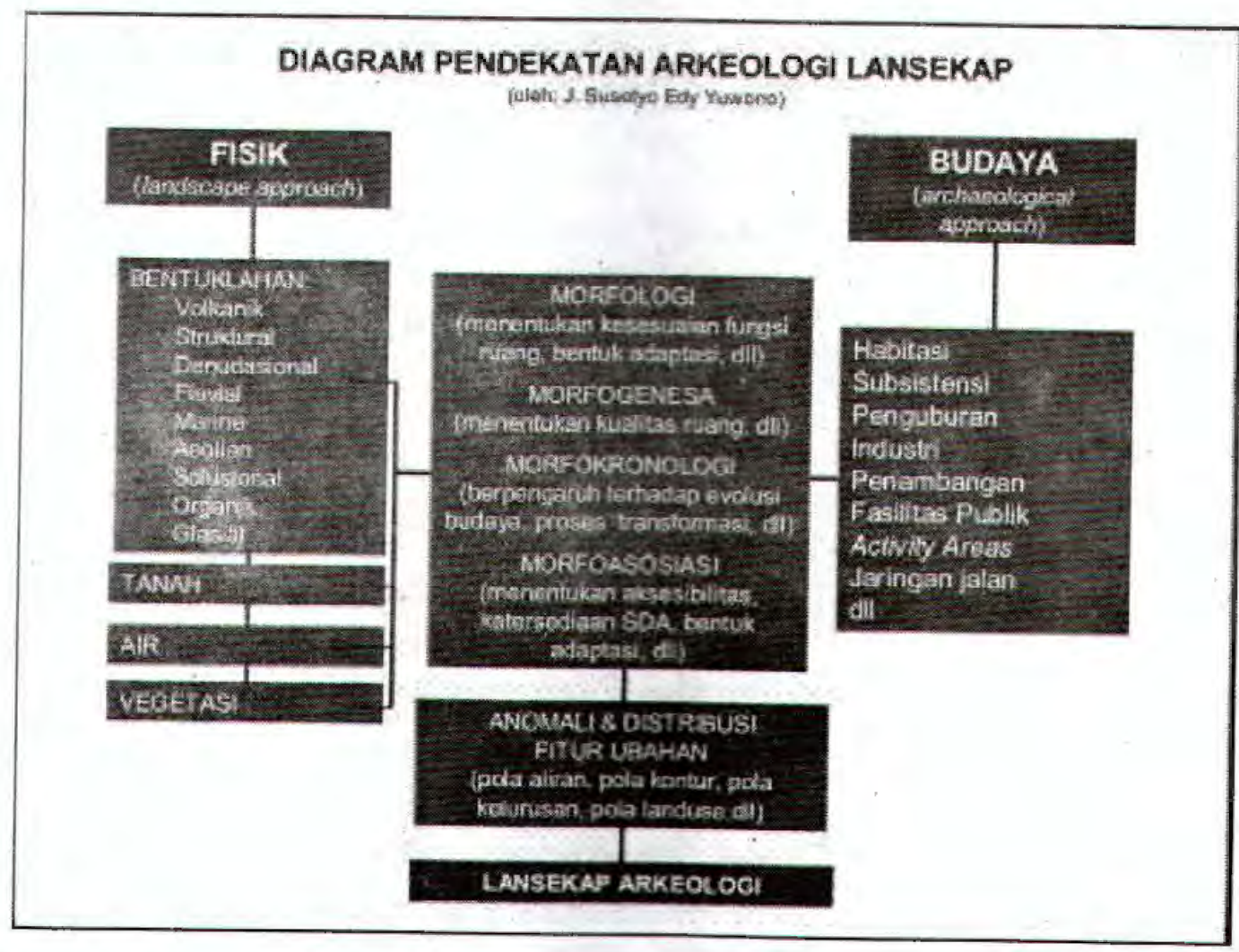


Gambaran di atas menekankan bahwa kajian arkeologi lansekap memerlukan ketersediaan bentuk-bentuk representasi spasial (peta, foto udara, dan atau citra satelit), baik dalam kedudukannya sebagai data, instrumen analisis, maupun hasil kajian. Karena suatu lansekap dibentuk oleh beberapa komponen, terutama bentuklahan, tanah, air, vegetasi, dan berbagai bentuk pengaruh manusia, maka diperlukan peta dasar dan berbagai peta tematik, termasuk struktur basisdatanya, agar dapat dilakukan analisis spasial. Bukan hanya untuk menghasilkan peta sebaran situs sebagaimana banyak dilakukan di Indonesia saat ini, melainkan sebuah peta tematik-sintetik yang mampu menggambarkan dan menjelaskan fenomena lansekap sesuai dengan tujuan dan skala penelitiannya.

Dari sisi keilmuan, tantangan berat dalam analisis arkeologi lansekap di Indonesia saat ini adalah bagaimana memvisualisasikan proses perubahan bentanglahan masa lalu akibat campur tangan manusia; dan bagaimana perubahan bentanglahan mengontrol strategi manusia dalam beradaptasi dan bermukim. Melalui penerapan SIG, terbuka kemungkinan untuk melakukan pemodelan-pemodelan spasial yang dapat mengatasi tantangan ini.

\section{Arkeologi Lasekap dan SIG}

\subsection{Belajar dari Kasus}

Salah satu contoh menarik mengenai penerapan SIG dalam kajian arkeologi lansekap telah dilakukan oleh Anne Gisiger dari Universitas Arkansas dalam thesisnya yang berjudul "A Spatial Analysis of Regional Human Adaptation Patterns Using Continental-Scale Data" (Gisiger 1996), dengan mengaplikasikan software Geographic Resources Analysis Support System (GRASS) GIS yang dikembangkan oleh the U.S. Army Construction Engineering Research Laboratories (CERL). Melalui analisis SIG berskala mega yang mengambil lokasi di kawasan Central Great Plains - Amerika, Gisiger berhasil merekonstruksi relasi spasial antara variabelvariabel lingkungan seperti pola aliran, distribusi elevasi, siklus pertumbuhan vegetasi dan rumput, perubahan temperatur rata-rata antara musim panas dan musim dingin, dan indeks kekeringan, dengan perubahan pola pemukiman dan pola adaptasi kelompok pemburu banteng liar dan 
kelompok hunter-gatherer-gardeners di Central Great Plains. Penelitian ini menerapkan metode overlay terhadap sejumlah peta tematik (di antaranya lihat peta 1,2,3), kemudian menganalisis hubungan spasial antar variabel pengamatan, melakukan pembobotan dan pengolahan spatial joint terhadap data atribut, serta pemodelan spasial secara time-series.

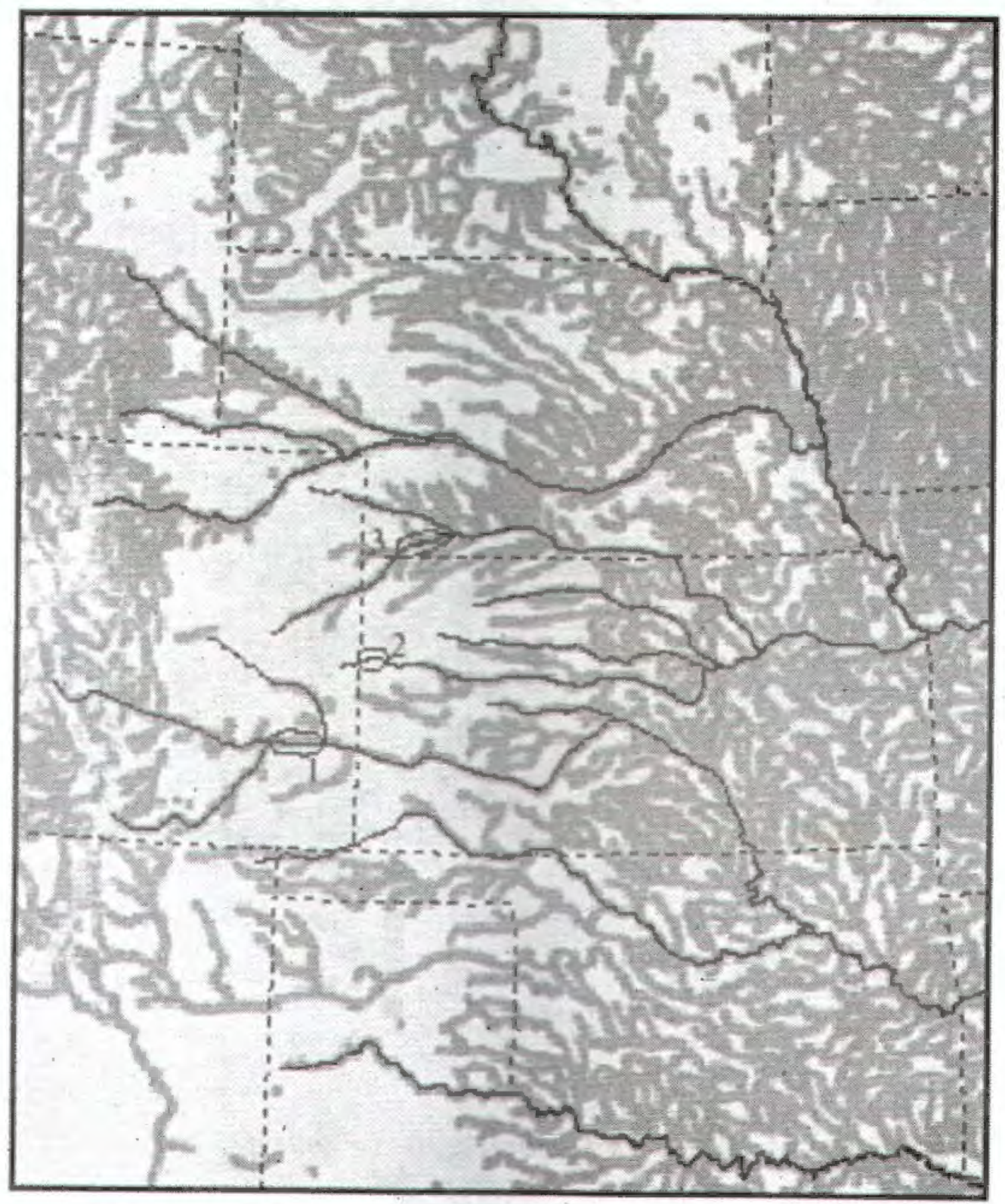

Peta 1. Pola Aliran di Central. Great Plains (Gisiger 1996) 


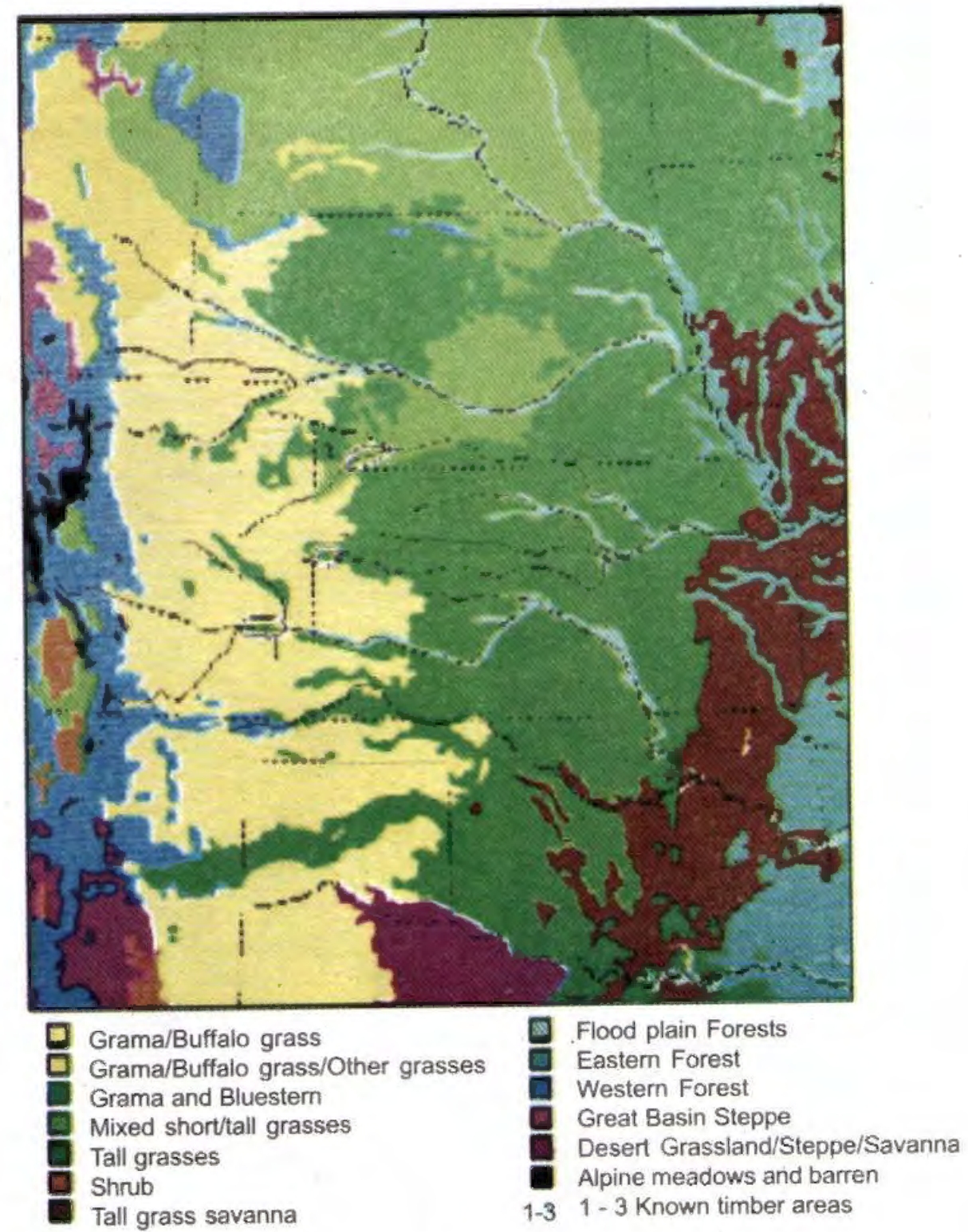

Peta 2. Potensi Vegetasi Alami di Central Great Plains (Gisiger 1996) 


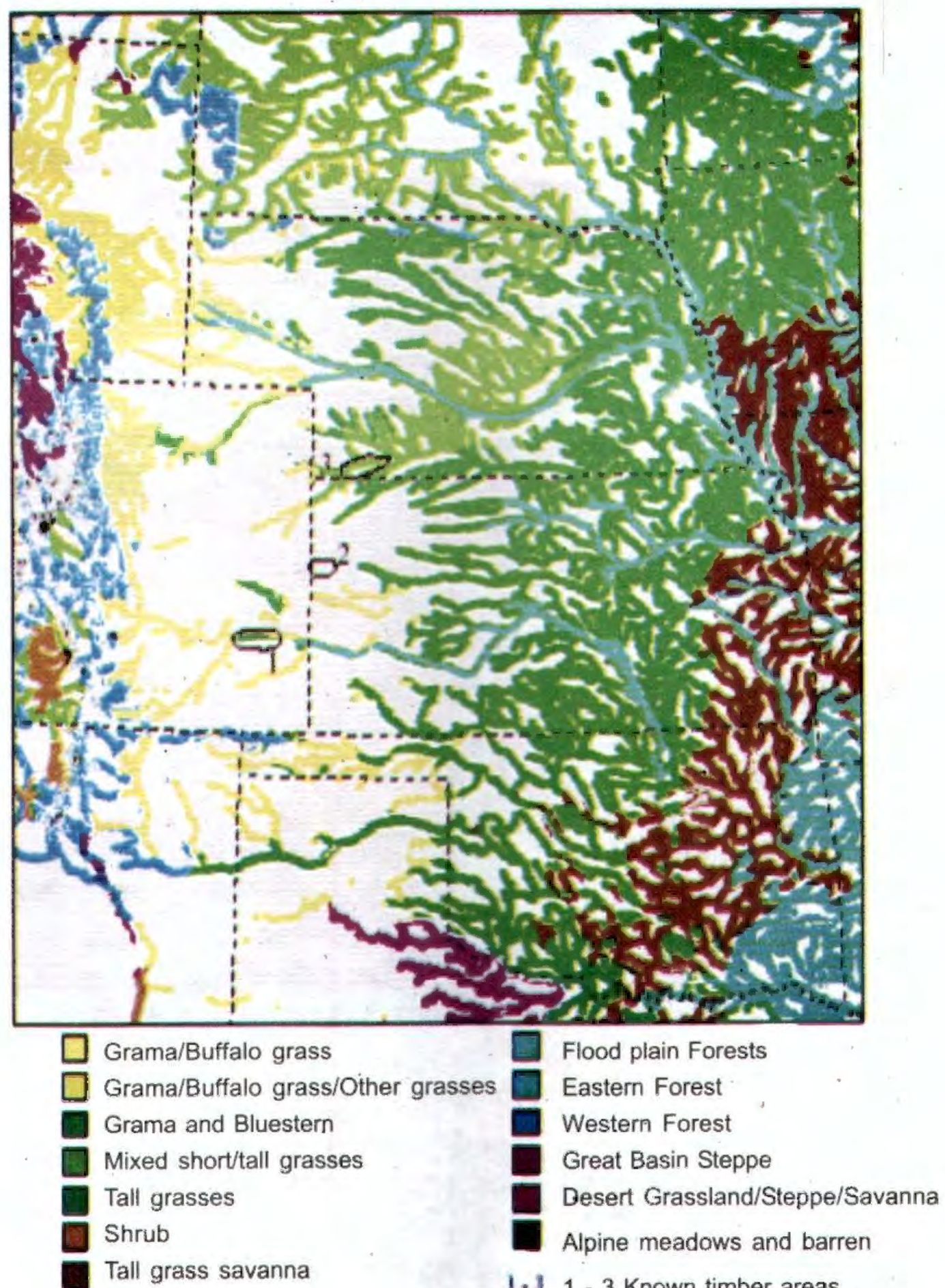

1.1 1 - 3 Known timber areas

Peta 3. Hasil Analisis terhadap Variabel Vegetasi Alami dan Pola Aliran di Central Great Plains (Gisiger 1996) 
Aplikasi SIG lainnya dapat dilakukan pada kajian arkeologi lansekap skala meso, mencakup situs dengan karakter lingkungan sekitarnya. Salah satu contohnya dilakukan di kawasan Rush, Arkansas, oleh The Arkansas Archaeological Survey. Limp, misalnya, dengan menggunakan software GRASS GIS, meninjau ulang konsep antropologi tentang cakupan situs (catchment area). Kawasan Rush yang terletak di dekat Sungai Buffalo, adalah daerah lembah yang dikelilingi oleh tebing yang tinggi dan curam. Model sebelumnya, yang mendefinisikan catchment area sebagai wilayah konsentris dengan satu situs sebagai pusatnya, ternyata tidak sesuai lagi. Dalam upaya menghasilkan model yang lebih sesuai dengan kondisi medan setempat, Limp menerapkan sistem buffer untuk membuat beberapa tingkat area. Hasilnya menunjukkan bahwa catchment area tidak berbentuk konsentris, melainkan memanjang mengikuti lembah sungai. Hasil korelasi antara catchment area dengan data vegetasi prasejarah menunjukkan bahwa komunitas prasejarah di lokasi tersebut banyak menggantungkan kehidupan mereka pada diet campuran hasil pertanian dan sumber makanan dari hutan (Gisiger 1996).

Saat ini, penulis bersama tim ekskavasi Kanal Kuna Komplek Candi Plaosan 2005, sedang menyelesaikan pengolahan data spasial skala meso untuk melihat korelasi antara bangunan candi, kanal kuna, dan data hidrologi sebaran sumur kuna di sekitar Plaosan. Analisis juga dilakukan terhadap pola aliran sungai-sungai di sekitar Plaosan (berdasarkan Peta Rupa Bumi skala 1:25.000 dan Foto Udara skala 1:20.000), hasil-hasil ekskavasi, dan hasil survei geohidrologi pada tahun 2003. Beberapa analisis spasial yang dilakukan dengan software ArcView GIS dan ArcGIS, akan dipakai untuk menjawab permasalahan sistem paleohidrologi kanal Plaosan dalam kaitannya dengan kondisi lansekap sekitar dan sebaran sumur kuna yang secara tipologis memiliki beberapa bentuk dan ukuran.

Contoh lainnya adalah kajian arkeologi lansekap skala makro, yang mencakup area kira-kira seluas $100-1000$ km2 (Delcourt \& Delcourt 1988, dalam Gisiger 1996). Allen dan Hasenstab, misalnya, menerapkan skala spasial ini untuk menganalisis pola-pola okupasi prasejarah Iroquois, dan mengungkapkan bahwa komunitas Iroquoian memilih lokasi-lokasi desa mereka di daerah yang sesuai untuk budidaya jagung. Selain memperhatikan sebaran situs dan unsur-unsur lansekapnya, mereka juga menganalisis variabel-variabel iklim dan mengolahnya dengan fasilitas SIG. 
Pada kasus lainnya, Allen mengaplikasikan program GIS ARC/Info yang berbasis vektor untuk menganalisis sistem perdagangan yang berlangsung di jaringan sungai-sungai di bagian timur kawasan Great Lakes, antara pertengahan abad XVI-XVIII Masehi. Melalui pemodelan yang dilakukan, Allen berhasil menemukan lokasi-lokasi baru yang berperan dalam jaringan perdagangan masa itu. Ditemukan pula bukti-bukti arkeologis dan historis yang menunjukkan bahwa pada 1550 , sejumlah komoditi dari Eropa sudah sampai ke pemukiman-pemukiman penduduk asli Amerika.

The South Carolina of Archaeology and Antrhopology (SCIAA) bekerja sama dengan The Earth Sciences and Resources Institute of the University of South Carolina (ESRI-USC) menyuguhkan contoh lain yang cukup menarik. Proyek gabungan ini mengembangkan 'predictive models' untuk menemukan situs-situs arkeologi di Carolina Selatan melalui pemrograman SIG. Data yang diperlukan meliputi: a) linear hydrography (untuk memplot sumber-sumber air permanen), b) hypsography (untuk mengidentifikasi variasi topografi), dan c) floodplains (dataran banjir). Dengan menganalisis citra satelit, ortofoto digital, peta topografi, dan hasil pembuatan Digital Elevation Model (DEM), dapat ditemukan 78 situs (Clement 2003).

SIG juga membuka kemungkinan untuk menangani kasus-kasus antar waktu dalam arkeologi lansekap melalui pengembangan metode analisis data budaya secara luas. Johnson dan Wilson, mencontohkan pembuatan Electronic Cultural Atlas Initiative (ECAI), dengan software ArcView GIS dan ArcExplorer yang dioperasikan melalui jaringan internet. Isu-isu penting yang dikembangkan adalah perekaman time-based cultural features, pengembangan interface untuk mendisplai peta-peta berbasis waktu, dan pembuatan peta-peta animatif. Hasilnya berupa sekumpulan data sets, layer-layer peta, kriteria-kriteria terpilih, simbolisasi, dan berbagai kasus spasial-temporal dari data budaya yang diakses (Johnson \& Wilson 2003).

\subsection{Menyikapi Keragaman Skala Kajian}

Banyak ahli sepakat bahwa pola-pola adaptasi manusia dipengaruhi oleh berbagai fenomena lingkungan dalam skala ruang dan waktu tertentu (Butzer 1987). Adaptasi terhadap kekeringan, misalnya, tidak dapat diidentifikasi melalui cakupan waktu pengamatan yang lebih pendek dibandingkan siklus kekeringan yang terjadi. Pada kasus lainnya, sumber (asal-usul) barang-barang perdagangan tidak dapat diidentifikasi jika 
jaringan perdagangan barang berlangsung pada skala keruangan yang lebih luas dibandingkan cakupan area yang dipelajari. Oleh karena itu, untuk menganalisis adaptasi manusia secara utuh di suatu bentanglahan diperlukan pendekatan pada skala keruangan dan waktu yang tepat.

Di antara empat skala keruangan seperti diklasifikasikan oleh Delcourt and Delcourt (1988, dalam Gisiger 1996), yaitu skala mikro, meso, makro, dan mega, arkeologi lansekap lebih banyak berurusan dengan skala meso hingga mega. Maka diperlukan tingkat kedetilan peta dan tingkat resolusi spasial citra yang sesuai dengan masing-masing cakupan, sebab representasi masing-masing elemen pada peta dipengaruhi oleh skala. $\mathrm{Hal}$ seperti ini di dalam kartografi berhubungan dengan generalisasi, yaitu upaya pemilihan dan penyederhanaan elemen-elemen peta, baik secara geometrik maupun konseptual. Generalisasi geometrik antara lain berupa pemilihan, penyederhanaan bentuk, penghilangan, eksagerasi atau pembesaran, dan pemindahan elemen akibat pembesaran. Sedangkan generalisasi konseptual berupa klasifikasi elemen-elemen tertentu, yang biasanya hanya diketahui oleh orang yang menguasai subjek yang akan dipetakan. Sebagai contoh, pada skala 1:50.000 terdapat 20 jenis tanah, jika diperkecil menjadi 1:100.000 harus dilakukan pengelompokan terhadap 20 jenis tanah tersebut sehingga jumlah jenisnya menjadi berkurang.

Tidak ada skala peta topografi tunggal yang sesuai untuk semua tingkat pengamatan, demikian pula dalam penggunaan foto udara. Skala 1:2.500 - 1:10.000, sesuai untuk identifikasi rinci unsur vegetasi, landuse, dan kenampakan geomorfik mikro, tetapi terlalu besar untuk analisis geologi dan geomorfologi skala tinjau yang membutuhkan analisis relasi antar unsur dalam wilayah yang luas. Foto udara skala $1: 15.000-1: 35.000$, umumnya sesuai untuk mengamati perbedaan ketinggian dan beberapa kenampakan minor lansekap. Sedangkan skala yang lebih kecil dari 1:35.000, paling sesuai untuk mengamati pola-pola regional. Pola aliran, misalnya, yang secara tidak langsung mencerminkan kondisi topografi (tingkat kemiringan lahan), kondisi litologi, dan struktur geologi suatu wilayah, mudah didelineasi dengan foto udara skala tersebut (Zuidam, 1985).

Penggunaan citra satelit juga memberi banyak kemajuan bagi kajian arkeologi lansekap. Apalagi dengan tersedianya berbagai jenis sensor citra yang relatif mudah diakses. Seperti dalam penentuan skala peta dan foto udara, kesesuaian tingkat resolusi citra dengan cakupan wilayah kajian 
juga perlu dipertimbangkan. Pada skala kajian meso setingkat kota, misalnya, sebaiknya digunakan citra satelit Quickbird Pankromatik (resolusi spasial 0,61 m) atau IKONOS Pankromatik (resolusi 0,83 m), sedangkan citra Landsat MMS dengan resolusi spasial $80 \mathrm{~m}$ lebih sesuai untuk kajian tingkat regional (makro). Masih banyak produk penginderaan jauh lainnya yang dapat diaplikasikan, mulai dari Small Format Aerial Photography (SFAP) hingga citra-citra hiperspektral yang luwes untuk disesuaikan dengan tujuan pengamatan (Danoedoro, 2004).

\section{Penutup: Tantangan Awal}

Kemampuan SIG sebagai piranti analisis keruangan memungkinkan dihasilkannya informasi baru melalui pengolahan gabungan terhadap data spasial multitema yang berbeda format. Peta-peta digital berbasis vektor, produk-produk penginderaan jauh berbasis raster, dan data lokasi dari GPS reciever, tidak lagi mengalami hambatan untuk dianalisis bersama berkat tersedianya berbagai fasilitas GIS.

Kondisi ini membuka peluang untuk meneruskan proyek-proyek penelitian yang sudah ada, sebagai suatu tantangan awal. Simak saja disertasi Mundardjito (1993) yang sudah mengakses data ratusan situs masa Klasik di wilayah Yogyakarta, termasuk di sekitar Prambanan. Keberhasilan analisis ekologis yang dicapainya, akan kian menarik dan membuka prospek kajian baru jika dikembangkan ke arah pemodelan-pemodelan spasial. Misalnya untuk memvisualisasikan kondisi palaeo-landscape Yogyakarta dan Prambanan pada masa Klasik secara time series. Dari visualisasi tersebut akan banyak informasi baru yang tidak mungkin diperoleh secara manual. Piranti Network Analyst dalam program ArcView GIS dan ArcGIS, misalnya, memungkinkan untuk memvisualisasikan jaringan transportasi masa itu; juga jaringan irigasi dan sanitasi kuna; hubungan antara aksesibilitas jalan - hieraki candi - dan keletakan klasterklaster pemukiman kuna; atau bahkan untuk menjawab isu kebencanaan ("maha pralaya") yang masih menjadi polemik hingga kini. Setidaknya untuk mengetahui bagian lansekap mana yang waktu itu paling parah diterjang lahar Merapi. Tidak tertutup pula kemungkinan untuk mengembangkan "Analisis Kesesuaian Lahan Masa Klasik", topik kontemporer yang sekarang ini paling banyak mengeksplor kemampuan SIG. 


\section{KEPUSTAKAAN}

Bintarto, R., 1991, "Geografi Manusia: Teori, Tema, dan Metodologi Penelitian", dalam Seminar Aplikasi Penelitian Geografi untuk Perencanaan Pengembangan Wilayah, Yogyakarta: Fakultas Geografi UGM.

Butzer, K. W. 1987. Archaeology as Human Ecology: Method and Theory for a Contextual Approach. Cambridge: Cambridge University Press.

Clement, Christopher Ohm, Sahadeb De, Robin Wilson Kloot, 2003, Using GIS to Model and Predict Likely Archaeological Sites, Sumber: http://gis.esri.com/library/userconf/proc01/ professional/papers/pap651/p651.htm; 10 April 2003.

Danoedoro, Projo (ed.), Sains Informasi Geografis: Dari Perolehan dan Analisis Citra hingga Pemetaan dan Pemodelan Spasial, Yogyakarta: Jurusan Kartografi dan Penginderaan Jauh Fak. Geografi UGM.

Dennell, R. W., 1987, "Geography and Prehistoric Subsistence", dalam J. M. Wagstaff (ed), Landscape and Culture: Geographical and Archaeological Perspectives,. hlm. 56-76. Oxford : Basil Blackwell.

Dibyosaputro, Suprapto, 1997, Geomorfologi Dasar, Yogyakarta: Fakultas Geografi UGM.

Gisiger, Anne, 1996, "A Spatial Analysis of Regional Human Adaptation Patterns Using Continental-Scale Data", Thesis, revised version, Arkansas: University of Arkansas.

Johnson, Ian, 1996, "GIS Applications in Archaeology: A short course", UISPP XIIIth Congress (Forli) Colloquium II Proceedings, Sydney: Archaeological Computing Laboratory University of Sydney. 
Johnson, lan \& Andres Wilson, 2003, "The TimeMap Project: Developing time-based GIS display for cultural data", Journal of GIS in Archaeology, Volume I p. 123-135., Sydney: University of Sydney - Australia,

Judge, W.J. \& Sebastian, L. (eds), 1988, Quantifying the Present \& Predicting the Past: Theory, Method, and Application of Archaeological Predictive Modeling. Denver, CO : US Dept. of the Interior, Bureau of Land Management. 650pp.

Moran, E. F.; 1990, "Ecosystem Ecology in Biology and Anthropology: A Critical Assessment", dalam E. F. Moran (ed), In The Ecosystem Approach in Anthropology. From Concept to Practice, University of Michigan Press, Ann Arbor, hlm. 3-40.

Mundardjito, 1993, "Pertimbangan Ekologi dalam Penempatan Situs Masa Hindu-Buda di Daerah Yogyakarta: Kajian Arkeologi Ruang Skala Makro", Disertasi, Jakarta: Program Pascasarjana Universitas Indonesia, Jakarta.

Prahasta, Eddy, 2004, Sistem Informasi Geografis: Tools dan PlugIns, cetakan 1, Bandung: Informatika,

Puspics UGM, 2004, Teknologi Sistem Informasi Geografis (SIG), Materi Pelatihan SIG - Operator, Fakultas Geografi UGM, Yogyakarta.

Rangkuti, Nurhadi, 1996, "Aplikasi Sistem Informasi Geografis dalam Penelitian Arkeologi Skala Kawasan", dalam Jurnal Penelitian Arkeologi no. 04 th. II/1996, hlm. 63-68; Yogyakarta: Balai Arkeologi,.

Suharyadi dan Projo Danoedoro, 2004, "Sistem Informasi Geografis: Konsep Dasar dan Beberapa Catatan Perkembangannya Saat ini", dalam Projo Danoedoro (ed.), Sains Informasi Geografis: Dari Perolehan dan Analisis Citra hingga Pemetaan dan Pemodelan Spasial hlm. 41-54, Yogyakarta: Jurusan Kartografi dan Penginderaan Jauh Fak. Geografi UGM.

Tucker, Greg \& Gary Lock, tt, Modelling the Stratigraphy, Geoarchaeology, and Aggregate Resources of English 
Valley Systems: Application of a Process-Based Landscape Evolution Model, Project Design, Oxford University.

Verstappen, H. Th, 1983, Applied Geomorphology: Geomorphological Surveys for Environmental Development, Amsterdam : Elsevier.

Vink, A.P.A., 1983, Landscape Ecology and Landuse, London - New York.: Longman

Yuwono, J. Susetyo Edy, 2004, Aplikasi SIG dalam Kajian Geoarkeologi Karstik: Studi Kasus di Gunungkidul - DIY, Laporan, Yogyakarta: Puspics UGM.

, 2005, 'Arkeologi Lansekap dalam Konteks Pengelolaan Sumberdaya Arkeologi', Workshop Pengelolaan Sumberdaya Arkeologi Tingkat Lanjut, Puslitbang Arkenas, Trowulan.

Zuidam, Robert A. van, 1985, Aerial Photo-Interpretation in Terrain Analysis and Geomorphological Mapping, The Hague: Smits Publisher.

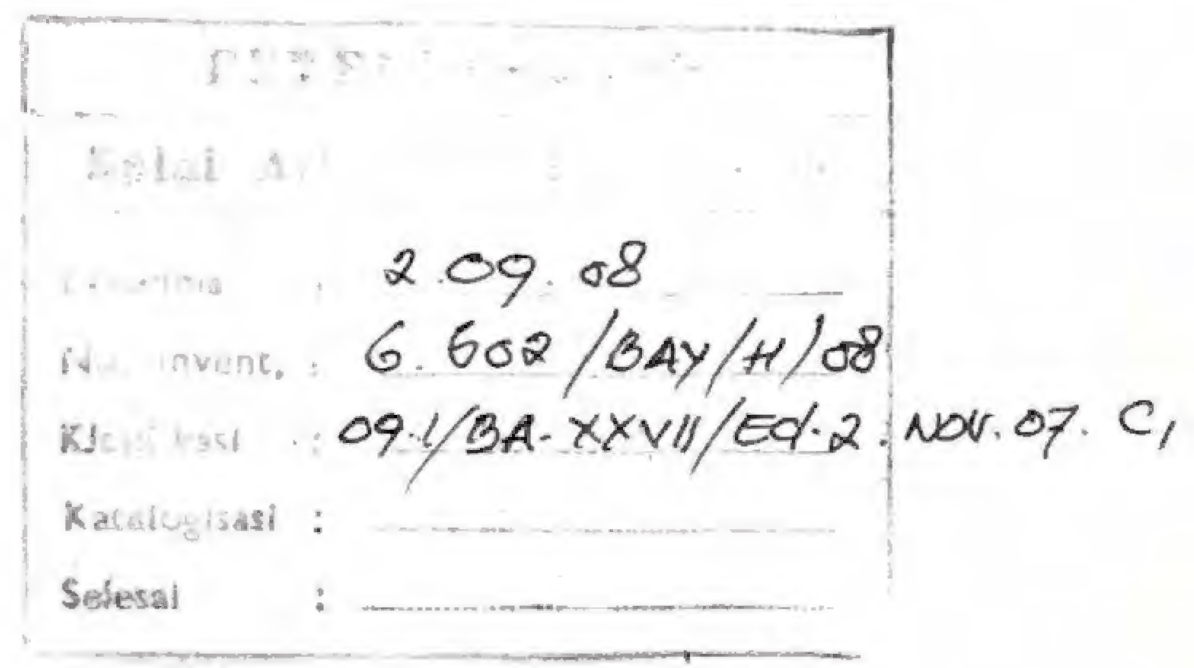

